\title{
Regional Student Mobility Calls for Convergence of China-ASEAN Higher Education
}

\author{
Qian Zeng \\ International Cooperation and Exchange Office \\ Yunnan University of Finance and Economics \\ Kunming, China \\ bmwii@foxmail.com
}

\author{
Jing Wang* \\ International Business School \\ Yunnan University of Finance and Economics \\ Kunming, China \\ wangjing@ynufe.edu.cn
}

\begin{abstract}
As an individual's mobility increases, educational competition and cooperation are shifting from the national level to the regional level. Student mobility therefore has become a bench mark to indicate the educational competitiveness of a certain region. In order to facilitate student mobility and enhance the convergence of regional higher education, regional cooperation mechanisms, such as EHEA, are established or under development. In the ASEAN and China context, the exceeding outbound flow and unbalanced intra-flow of students suggested that regional convergence shall be an effective option to cope with concerns of exceeded outflow of students, brain drain, as well as losing economic benefits. Besides, two opportunities and one challenge are highlighted because they are crucial when China and ASEAN start to forge a regional higher education convergence.
\end{abstract}

Keywords—higher education, student mobility, convergence

\section{INTRODUCTION}

The development of modern technology endows people with more mobility and facilitates the linkage between an individual and the entire world. As a result, the national boundaries of economy and education are dimmed to some extent. Just like the economic globalization where competition and cooperation is shifting from the national level to the regional level, the same is true with internationalization of education. One prominent phenomenon of this trend is the large scale of student mobility between different geographical regions. Student mobility, on one hand, helps different regional higher education systems to participate in the educational internationalization; on the other hand, serves as a benchmark to assess the competitiveness of the educational systems. If we regard the different education systems as different "manufacturers," who produce educational products and services, then, the international students shall be considered as "customers" who have the ultimate right to choose their products and services. In this sense, the attractiveness of international students can be regarded as the competitiveness of a certain educational system in the international education arena.

Take an overlook at the global higher education in real life today, the regional higher education cooperation is reshaping the landscape of higher education. In Europe, the European Higher Education Area (EHEA) was established in 2010 based on the concrete steps and long-lasting efforts of the Bologna Process. EHEA is by far the most successful and influential case of regional higher education harmonization. Even some scholars of the United States have warned in World Education News and Reviews (WENR) that the US dominance over the global international student market is challenged by EHEA. By a thorough study of the core components of EHEA, such as Qualification Frameworks, ECTS, degree cycles and Diploma Supplements (DS), Adelman concludes that even the higher education system of the United States need to adopt some of the features of Bologna Process and put forward constructive suggestions for the U.S. higher education system to change [1] Brookes and Huisman point out that regional higher education convergence is needed for the U.S. and its neighbors, however, the higher education convergence in this particular arena in the past is still labeled as uneven, piecemeal and even haphazard [2]. In Latin American, the topic of higher education convergence induces different point of views. With a comparative study of the MERCOSUR-Educativo in Latin America and the Bologna Process in Europe in terms of their content, governance, evolution, implementation, and external influence, Verger and Hermo conclude that the economic integration of Latin American and globalization are the main driven force for the attempt of convergence of higher education[3]. Some scholars have different interpretation on the same issue. Brunner argue that although Latin American countries share the advantages of geography, history, and languages, the development of a common Latin American higher education and research area still faces obvious difficulties rooted from the governments and institutes[4]. In Asia, several higher education cooperation mechanisms have been in existence for a long period of time, such as Southeast Asian Ministers of Education Organization (SEAMEO)and ASEAN Education Ministers Meeting (ASED). Practical programs are being carried out by implementing bodies as SEAMEO Regional Centre for Higher Education and Development (SEAMEO-RIHED), ASEAN Senior Officials on Education (SOM-ED) and ASEAN University Network (AUN). These cooperative mechanisms can be seen as the prototype of EHEA in China-ASEAN region. One of the common goals of all these cooperative mechanisms is to facilitate student mobility. With the support from various cooperative mechanisms, student mobility in the ChinaASEAN region is booming.

\footnotetext{
* Corresponding author
} 


\section{TRENDS AND CONCERNS OF STUdENT MOBILITY OF CHINA- ASEAN REGION}

Regarding student mobility in China-ASEAN region, two perspectives shall be noted; namely, external-flow beyond the region, and internal-flow within the region. For the externalflow, according to statistics (Figure 1), only $10 \%$ of Southeast Asian students chose to study in Southeast Asian region in 2012. In contrast, the top three hosting countries along, namely Australia, the United States and the United Kingdom, attracted almost $60 \%$ of the outbound Southeast Asian students in 2012. For the internal flow, student mobility between China and ASEAN increased steadily. According to the statistics released at the Press Conference of the 9th China-ASEAN Education Cooperation Week, the number of ASEAN students studying in China reached 71,101 in 2015, and the number of Chinese students studying in ASEAN reached 39,662. Further studies show that, for ASEAN countries and China, the intra-flow of students is imbalanced. Take Laos and Myanmar as an example, the number of Laos and Myanmar students in China have increased by approximately 13 and 18 times respectively from 2000 to 2013 , but they are not the popular destination countries for most of Chinese students (Table 1) [5]. The exceeding out-bound student mobility and unbalanced internal student mobility of the China-ASEAN region may incur concerns as follow:

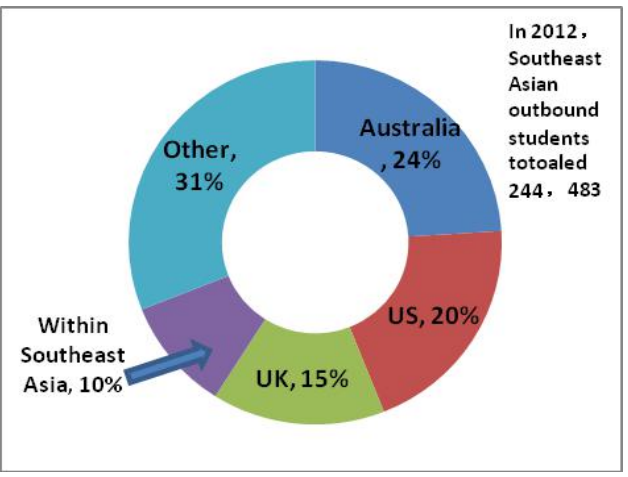

Fig. 1. Southeast Asian Outbound Students by Destination in 2012

Source: UNESCO's Global Flow of Tertiary-level students and Can U.S. compete in the Southeast Asian Transnational Education Market?, World Education Services 2015
Firstly, although the Intra-flow of students within ChinaASEAN region is growing, it is unbalanced for a number of countries. Countries with better education systems, stronger economic conditions and cost-efficient advantages like Singapore, China, and Malaysia are hosting comparatively more students, while countries like Laos, Myanmar, and Cambodia are hosting fewer students. In the long term, such unbalanced student flow may lead to one-direction student mobility which will destabilize the sustainability of regional cooperation.

Secondly, out flow of students may result in concerns of brain drain. The students who go to developed countries for further study shall be well educated. However, due to expensive tuition and high living costs, they are also expected to gain more. It is very common for these students to choose to work and live in countries with higher income and better career opportunities, rather than returning back to their home countries. This problem often becomes even more serious when their home countries are a lower-income developing countries which desperately needs talents.

Thirdly, as mentioned above, China and ASEAN countries are "losing" students. The huge exceeding outbound student mobility number revealed a fact that there is an outflow of money, as well as a loss of domestic and regional job positions. Although there are no accurate statistics show the amount of money that students from China and ASEAN countries bring to the hosting countries outside this region, it is common for their tuition fees to be doubled or tripled in comparison to native students. Furthermore, once they start to study abroad, they begin to generate job positions for the hosting country. Take the United States for example, according to Open Doors 2015 Data released by the Institute of International Education (IIE), it is estimated that foreign students have contributed approximately over $\$ 30$ billion to the US economy during the 2014/15 academic year.

To cope with the problems mentioned above, realizing the convergence of China-ASEAN higher education should be one optimal solution. According to EHEA experiences, a highly convergent higher education space shall surely facilitate the student mobility by means of providing comparable degree

TABLE 1. Number of ASEAN StUdents StUdy In China By COUNTRY OF ORIGIN

\begin{tabular}{|c|c|c|c|c|c|c|c|c|c|c|}
\hline $\begin{array}{l}\text { Country } \\
\text { Year }\end{array}$ & PHL & KHM & LAO & MYS & MMR & THA & BRU & SGP & IDN & VNM \\
\hline 2000 & 217 & 121 & 298 & 490 & 123 & 667 & 27 & 854 & 1,947 & 647 \\
\hline 2001 & 456 & 89 & 312 & 632 & 149 & 860 & 4 & 344 & 1,697 & 1,170 \\
\hline 2003 & 602 & 139 & 403 & 841 & 232 & 1,554 & 4 & 551 & 2,563 & 3,487 \\
\hline 2004 & 1,375 & 180 & 509 & 1,241 & 397 & 2,371 & 6 & 929 & 3,750 & 4,382 \\
\hline 2005 & 2,176 & 188 & 569 & 1,589 & 494 & 3,594 & 7 & 1,322 & 4,616 & 5,842 \\
\hline 2006 & 1,512 & 221 & 833 & 1,743 & 538 & 5,522 & 10 & 1,392 & 5,652 & 7,310 \\
\hline 2007 & 1,335 & 225 & 943 & 1,908 & 645 & 7,306 & 13 & 1,480 & 6,590 & 9,702 \\
\hline 2008 & 2,363 & 330 & 1.161 & 2,114 & 654 & 8,476 & 36 & 2,155 & 7,084 & 10,396 \\
\hline 2009 & 2,273 & 406 & 1,557 & 2,792 & 1,026 & 11,379 & 22 & 3,198 & 7,926 & 12,247 \\
\hline 2010 & 2,989 & 502 & 1859 & 3,885 & 972 & 13,177 & 31 & 3608 & 9,539 & 13,018 \\
\hline 2011 & 2,662 & 775 & 2,395 & 4,259 & 1,529 & 14,145 & 36 & 4,483 & 10,957 & 13,549 \\
\hline 2012 & 2,642 & 1,336 & 2,773 & 6,045 & 1,872 & 16,675 & 44 & 4,250 & 13,144 & 13,038 \\
\hline 2013 & 2,917 & 1,390 & 3,999 & 6,126 & 2,299 & 20,106 & 29 & 5,290 & 13,492 & 12,799 \\
\hline
\end{tabular}


recognition system, convenient credit transfer system and commonly acknowledged quality assurance criteria. In this case, the number of Intra-flow students will further increase and the pressure of unbalanced flow will be reduced to some extent. Furthermore, the increased intra-flow of students means less concern about brain drain. Students who studied aboard within the China-ASEAN region will more likely to return home due to lower overseas study costs and lower career expectation comparing to their counterparts in Europe or U.S. Lastly, the increase of intra-flow students will ultimately help to improve the educational competitiveness of this region. Most countries in the China-ASEAN region are developing countries, and their higher education requires more inputs. Intra-flow students may contribute to the improvement of regional higher education. In general, the convergence of China-ASEAN higher education will eventually create a winwin situation, not only for the member countries in terms of improving their higher education competitiveness and obtaining more discourse power in the global education area, but also for its young people in terms of providing broader, easier and more affordable accessibility to international education opportunities.

In reality, although the process of convergence of ChinaASEAN higher education can be vividly described as "Rome is not built in a day", visionary strategies and solid measurements have been carried out by the governments and institute of higher learning in this region. In 2010, the ministers of education from the ASEAN countries and China jointly signed the Guiyang Declaration which may function as the action plan for future cooperation. The China-ASEAN double 100,000 Student Mobility Plan, which was designed to increase both the number of Chinese students studying in ASEAN and the number of ASEAN students studying in China to 100,000 respectively by 2020 , is expected to be fulfilled ahead of its schedule. All these positive gestures show the strong will and determination of the government, and positive attitude of the stakeholders in forging a regional convergence of higher education.

\section{OPPORTUNITIES AND CHALLENGES}

Despite of the fruitful achievements, the ASEAN and China still face various new opportunities and challenges in propelling the convergence of regional higher education and intra-flow of students. As Welch emphasizes that due to the increasing globalization of higher education, both China and the ASEAN adopt competitive and cooperative strategies in regional higher education arena, and these moves not only create new challenges but also open up prospects for new regional alliances [6]. Among these new opportunities and challenges, two opportunities and one challenge should be highlighted.

The first opportunity comes from the determination of building up the regional identity. As the ASEAN motto reads "one vision, one identity, one community," ASEAN is building up its own regional identity on the international stage. In order to achieve this goal, it is necessary to build up awareness and sense of pride of being part of the ASEAN among the young people, particularly those of school age. In this sense, the convergence of regional higher education and the promotion of student mobility within this region are highly in accordance with this strategic goal, because it can increase the awareness and sense of pride of the regional identity via barrier-free student mobility, mutual recognition of credits and degrees, unified quality assurance system or other means.

The second opportunity is based on three existing credit transfer systems in Asia. ASEAN and China are exploring fundamental cooperative mechanisms to ensure the sustainable convergence of higher education and smooth regional student mobility. Such mechanisms mainly focus on issues of quality assurance, degree acknowledgement and credit transfer. Among them, credit transfer is of great importance, and therefore, has drawn much attention. Currently there are three existing credit transfer systems affecting the ASEAN and China region. First, UMAP Credit Transfer Scheme (UCTS), developed by University Mobility in Asia and the Pacific (UMAP) in 1997, hosts 438 member universities and 23 countries and region including 7 ASEAN member countries and China. Second, ASEAN Credit Transfer System (ACTS) developed by ASEAN University Network (AUN) in 2009, hosts 10 ASEAN member countries and its partner countries like Japan and China. Third, the ASEAN International Mobility for Students (AIMS) developed by South East Asian Ministers of Education Organization-Regional Institute for Higher Education and Development (SEAMEO-RIHED), hosts 60 universities in Malaysia, Indonesia, Thailand, Vietnam, Philippines, Brunei Darussalam and Japan. The phenomenon of three co-existing credit transfer system (CTS) has indicated that, on one hand, the CTS is crucial for student mobility and convergence of higher education; on the other hand, establishing a unified and practical CTS needs deliberate consideration, efficient coordination and generous compromise if necessary. With the experiences obtained in participating in the above three CTS, it would be easier or faster for ASEAN and China to improve or create unified CTS when necessary.

For the challenges, ASEAN and China are facing dozens of challenges, such as fierce competition in the international student market, under-developed educational systems. However, the most vital challenge comes from inside and the question is what kind of coordinating mechanism should be adopted to provide an efficient supranational leadership towards a higher education convergence within this region. EU adopted the Open Method of Coordination (OMC), which proved to be efficient in European background. A similar coordinating mechanism also can be found in the ASEAN Socio-Cultural Community Blueprint.[7] Then, here comes the question: Can China and ASEAN create a supranational coordination system which will be efficient and accepted by both sides, even if there are still few adverse voices against China from time to time?"

\section{ACKNOWLEDGMENT}

This work was supported by Youth Research Project on Humanity and Social Science of Ministry of Education Project number: 11YJC880154 and Scientific Research Project of Yunnan Provincial Department of Education, Project Number 2010 Y114. 
I would like to extend my heartfelt gratitude to my coauthor whose dedicated work and support from the very beginning to the completion of this paper. I also would like to thank the Ministry of Education and Yunnan Provincial Department of Education which supported this research by granting two research projects to me and my co-author respectively. Lastly, I offer my regards to all of those who supported us in any respect during the completion of this work.

\section{REFERENCES}

[1] C. Adelman, "The Bologna Club: What U.S. Higher Education Can Learn from a Decade of European Reconstruction," Institute for Higher Education Policy, 2008
[2] M. Brookes, and J. Huisman, "The eagle and the circle of gold stars: does the Bologna Process affect US higher education?" Higher Education in Europe, vol. 34, 2009, pp. 3-23.

[3] A. Verger, and J.P. Hermo, "The governance of higher education regionalization: comparative analysis of the Bologna Process and MERCOSUR - Educativ0," Globalisation Societies \& Education, vol. 8, 2010, pp. 105-120.

[4] J.J. Brunner, "The Bologna Process from a Latin American Perspective," Journal of Studies in International Education, vol. 13, 2009, pp. 417-438.

[5] B. Fang, "On Changing Trends of China's Education of ASEAN students in the past 15 years," Comparative Education Review, 2015, pp. 77-86

[6] A. Welch, "The Dragon, The Tiger Cubs and Higher Education: Competitive and Cooperative China-ASEAN Relations in the GATS Era," ASEAN Industries and the Challenge from China, Palgrave Macmillan UK, 2011.

[7] ASEAN Secretariat, "ASEAN Socio-cultural Community Blueprint," Chapter III: Implementation and Review of the ASCC Blueprint, 2009 